\title{
POTENSI AKTIVITAS ANTIBAKTERI DARI FRAKSI ETIL ASETAT DAUN JAMBU AIR [Eugenia aqueum (Burn F.) Alston] TERHADAP STHAPHYLOCOCCUS AUREUS DAN ESCHERICHIA COLI
}

\author{
${ }^{1}$ Ratu Choesrina, ${ }^{2}$ Suwendar, ${ }^{3}$ Lanny Mulqie, ${ }^{4}$ Dieni Mardliyani \\ 1,2,3,4 Program Studi Farmasi, FMIPA, Universitas Islam Bandung, Indonesia \\ email: ${ }^{1}$ choesrinal@gmail.com
}

\begin{abstract}
ABSTRAK
Staphylococcus aureus (S. Aureus) adalah termasuk penyusun flora normal jenis Gram positif. Tetapi apabila jumlahnya berlebih akan menjadi patogen pada manusia. Begitu pula dengan Escherichia coli (E. coli) yang merupakan bakteri gram negatif Antibakteri yang tersedia umumnya memiliki spektrum luas sehingga efek sampingnya dapat merusak flora normal bila digunakan jangka panjang. Flavonoid senyawa fenolik dan tannin dimungkinkan berkhasiat antibakteri. Sediaan uji berupa seri konsentrasi fraksi etil asetat daun jambu air [Eugenia aqueum (Burn F.) Alston] (50\%; 25\%; 12,5\%; 6,25\%; 3,13\%; 1,56\%; 0,78\%; $0,31 \%)$. Uji aktivitas antibakteri ini menggunakan metode difusi agar dengan sumur untuk menentukan Konsentrasi Hambat Minimum (KHM), serta tipe kerja terhadap bakteri uji (dengan metode turbidimetri) dan kemudian dibandingkan dengan antibiotik pembanding yaitu tetrasiklin dengan menggunakan analisis regresi. Fraksi etil asetat daun jambu air memiliki aktivitas sebagai anti bakteri terhadap $S$. aureus dan E. coli dengan nilai KHM masing-masing $12,50 \%$. Kesetaraan aktivitas terhadap $S$. aureus dari $1 \mathrm{~g}$ fraksi etil asetat terhadap tetrasiklin adalah 0,0295 g sedangkan terhadap E. coli adalah 0,0186 g. Fraksi etil asetat daun jambu air berpotensi sebagai antibakteri; Tipe kerja fraksi etil asetat cenderung bakterisid baik terhadap $S$. aureus maupun $E$. coli.
\end{abstract}

Kata Kunci: Antibakteri, Staphylococcus aureus, Escherichia coli

\begin{abstract}
Staphylococcus aureus (S. Aureus) is a constituent of the Gram positive type of normal flora. But if the amount is excessive it will become a pathogen in humans. Likewise with Escherichia coli (E. coli) which is a Gram negative bacterium.Antibacterials that are available generally have a broad spectrum, so that side effects can damage normal flora if used in long-term. Flavonoids, phenolic compounds and tannins had antibacterial properties. Test preparation is the series of water apple leaves's ethyl acetate fraction [Eugenia aqueum (Burn F.) Alston] ( 50\%; 25\%; 12,5\%; 6,25\%; 3,13\%; 1,56\%; 0,78\%; $(50 \% ; 25 \% ; 12.5 \% ; 6.25 \% ; 3.13 \% ; 1.56 \% ; 0.78 \% ; 0.31 \%)$.Values antibacterial activity agar diffusion was used to determine MIC, and work type against test bacteria (with turbidimetry method) and then compared to the comparative antibiotic tetracycline using regression analysis. Ethyl acetate fraction of water apple leaves had anti-bacterial activity against $S$. aureus and E. coli with KHM values of $12.50 \%$. Equality of activity against $S$. aureus from $1 \mathrm{~g}$ of ethyl acetate fraction to tetracycline was $0.0295 \mathrm{~g}$ whereas for E. coli it was $0.0186 \mathrm{~g}$. Ethyl acetate fraction of water apple leaves has the potential as an antibacterial; The type of ethyl acetate fraction tends to be bactericidal in both S. aureus and E. coli.
\end{abstract}

Keywords: Antibacterial, Staphylococcus aureus, Escherichia coli 


\section{PENDAHULUAN}

Staphylococcus aureus (S. Aureus) adalah termasuk penyusun flora normal jenis Gram positif. Tetapi apabila jumlahnya berlebih akan menjadi patogen pada manusia. Begitu pula dengan Escherichia coli (E. coli) yang merupakan bakteri gram negatif. Antibakteri yang tersedia umumnya memiliki spektrum luas, sehingga efek sampingnya dapat merusak flora normal bila digunakan jangka panjang, serta efek samping lainnya seperti resistensi (Cosgrove dkk 2003). Oleh karena itu perlu dilakukan penelitian guna mendapatkan antibakteri yang lebih baik. Penelitian ini adalah tahap awal untuk mendapatkan anti bakteri yang lebih baik dengan melihat potensinya (Rybak dan Aeschlimann, 2008).

Menurut hasil penelitian Hariyati dkk pada tahun 2015, ekstrak etanol daun jambu air memiliki potensi besar sebagai sumber antimikroba. Dimana flavonoid, senyawa fenolik dan tanin yang diantaranya terkandung dalam daun jambu air dimungkinkan berkhasiat antibakteri (Aponno dkk, 2014; Rosidah dan Afizia, 2012; Anita dkk, 2014, Ratna, 2016; Hamidah dkk, 2017). Etanol dapat dikatakan sebagai pelarut universal, sehingga perlu diketahui senyawa dengan sifat kelarutan manakah yang memiliki aktivitas antibakteri.
Tujuan dari penelitian ini adalah membuktikan secara ilmiah ada tidaknya potensi aktivitas antibakteri dari fraksi etil asetat daun jambu air terhadap S. aureus dan E. coli, KHM (Konsentrasi Hambat Minimum) dan tipe kerjanya. Manfaat dari penelitian ini adalah untuk dapat memberikan masukan bagi penelitian selanjutnya agar hasil penelitiannya bisa menjadi lebih lengkap guna memperoleh antibakteri yang lebih baik.

\section{METODE PENELITIAN}

\subsection{Alat, Bahan dan Bakteri Uji}

Alat yang digunakan adalah timbangan analitik, perkolator, corong pisah, inkubator, spektrofotometer UVvisible, vortex, cawan petri, jarum ose, lampu spiritus, autoklaf, pipet Eppendorf, pipet ukur dan alat-alat gelas yang lazim dipergunakan di laboratorium Farmakologi.

Bahan yang digunakan adalah daun jambu air, etanol 96\%, etil asetat, tetrasiklin, air kaldu, nutrien agar, $\mathrm{NaCl}$ fisiologis, dimetilsulfoksida (DMSO), kapas berlemak, aluminium foil dan air steril.

Bakteri uji yang digunakan adalah S.aureus dan E.coli yang diperoleh dari Laboratorium Farmasi Terpadu Unit D, Program Studi Farmasi, Fakultas Matematika dan Ilmu Pengetahuan Alam, Universitas Islam Bandung. 


\subsection{Metode}

Penelitian meliputi pengumpulan bahan uji (daun jambu air), pembuatan simplisia (Depkes RI, 1985), pembuatan fraksi etil asetat uji aktivitas antibakteri. Penelitian dilaksanakan di Laboratorium Farmasi Terpadu Unit D, Program Studi Farmasi, Fakultas Matematika dan Ilmu Pengetahuan Alam, Universitas Islam Bandung.

Pembuatan ekstrak etanol dilakukan dengan metode maserasi menggunakan etanol 96\% lalu dilakukan ekstraksi caircair menggunakan etil asetat (Suwendar dan Hazar, 2013). Kemudian dibuat suatu seri konsentrasi (50\%; 25\%; 12,5\%; $6,25 \% ; 3,13 \% ; 1,56 \% ; 0,78 \% ; 0,31 \%$.

Uji aktivitas antibakteri ini menggunakan metode difusi agar dengan sumur untuk menentukan KHM, spektrum kerja, serta tipe kerja terhadap bakteri uji (dengan metode turbidimetri), untuk kemudian dibandingkan dengan antibiotik pembanding yaitu tetrasiklin dengan menggunakan analisis regresi (Sukandar dkk, 2006).

\section{HASIL DAN PEMBAHASAN}

Diameter zona hambat yang didapat dari fraksi etil asetat terhadap S. aureus dan E. coli terlihat pada Tabel 1 dibawah ini :
Tabel 1. Diameter Zona Hambat Fraksi Etil Asetat terhadap S. aureus dan E. coli

\begin{tabular}{|c|c|c|}
\hline \multirow{2}{*}{$\begin{array}{c}\text { Konsentrasi } \\
(\%)\end{array}$} & \multicolumn{2}{|c|}{$\begin{array}{c}\text { Diameter zona } \\
\text { hambat }(\mathbf{c m})\end{array}$} \\
\cline { 2 - 3 } & S. aureus & $\boldsymbol{E}$. coli \\
\hline \multirow{2}{*}{50} & $\begin{array}{c}1,50 \pm \\
0,03\end{array}$ & $\begin{array}{c}1,60 \pm \\
0,08\end{array}$ \\
\hline \multirow{2}{*}{25} & $1,37 \pm$ & $1,44 \pm$ \\
& 0,06 & 0,05 \\
\hline \multirow{2}{*}{12,50} & $1,16 \pm$ & $1,10 \pm$ \\
& 0,03 & 0,01 \\
\hline 6,25 & - & - \\
\hline 3,13 & - & - \\
\hline 1,56 & - & - \\
\hline 0,78 & - & - \\
\hline 0,31 & - & - \\
\hline Tetrasiklin & $1,76 \pm$ & $1,56 \pm$ \\
0,008 & 0,04 & 0,78 \\
\hline
\end{tabular}

Berdasarkan tabel diatas terlihat bahwa fraksi etil asetat memiliki aktivitas antibakteri terhadap S. aureus (bakteri gram positif) dan E. Coli karena diameter hambatnya $\geq 6 \mathrm{~mm}$, sesuai dengan kriteria Bell (Rosidah dan Afizia, 2012). Aktivitas fraksi etil asetat terhadap $S$. aureus lebih kuat dibandingkan terhadap E. Coli. Aktivitas anti bakteri tersebut dikarenakan tannin diduga dapat merusak struktur membran bakteri menginaktivasi enzim destruksi atau juga inaktivasi fungsi materi genetik (Aponno dkk, 2014; Rosidah dan Afizia 2012); Flavonoid dapat mengganggu metabolisme dengan mengikat protein (Poeloengan dan Praptiwi, 2010; Anita dkk 2014), merusak dinding sel (Nugraha dkk, 2016), sebagai antioksidan (Suwendar dkk, 2014). 
Tipe kerja sediaan uji terhadap $S$, aureus dengan metode turbidimetri dapat dilihat pada Tabel 2 berikut ini :

Tabel 2. Perkembangan Pertumbuhan S. aureus Berdasar Nilai Absorbansi Setelah Pemberian Fraksi Etil Asetat

\begin{tabular}{|c|c|c|c|c|c|c|c|c|c|c|}
\hline \multirow{2}{*}{$\begin{array}{c}\text { Sistem } \\
\text { uji }\end{array}$} & \multicolumn{8}{|c|}{ Nilai absorbansi dalam interval tiap 30 menit } \\
\cline { 2 - 11 } & $\mathbf{0}$ & $\mathbf{3 0}$ & $\mathbf{6 0}$ & $\mathbf{9 0}$ & $\mathbf{1 2 0}$ & $\mathbf{1 5 0}$ & $\mathbf{1 8 0}$ & $\mathbf{2 1 0}$ & $\mathbf{2 4 0}$ & $\mathbf{2 7 0}$ \\
\hline Kontrol & 0,042 & 0,090 & 0,124 & 0,192 & 0,254 & 0,297 & 0,322 & 0,348 & 0,360 & 0,374 \\
\hline $\begin{array}{c}\text { Fraksi } \\
\text { etil } \\
\text { asetat }\end{array}$ & 3,436 & 3,436 & 2,913 & 3,135 & 3,010 & 2,913 & 2,737 & 2,612 & 1,142 & 2,658 \\
\hline
\end{tabular}

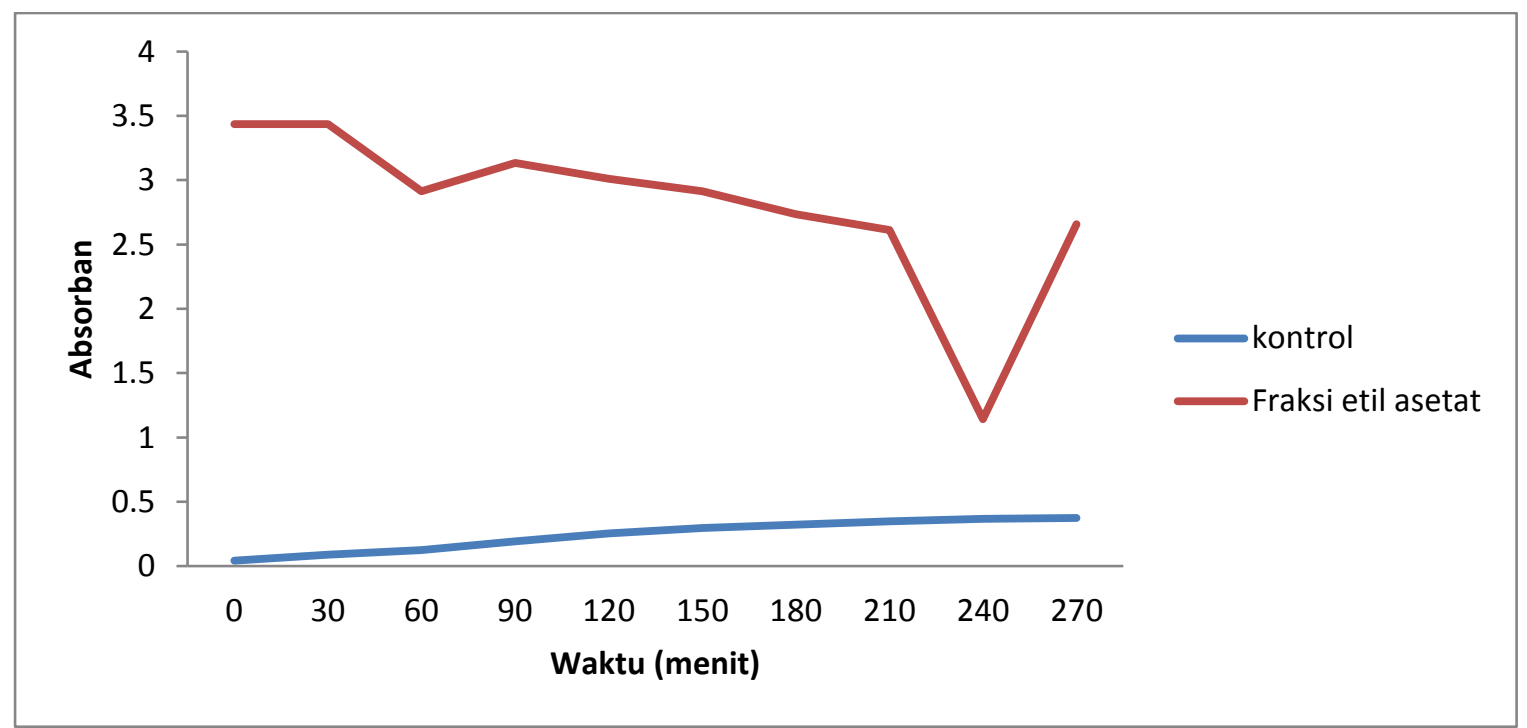

Gambar 1. Perkembangan Pertumbuhan S. aureus setelah Pemberian Fraksi Etil Asetat Berdasar Nilai Absorbansi

Terlihat bahwa pada garis kurva fraksi etil asetat tidak terjadi pertumbuhan, tetapi terjadi penurunan sampai dengan menit ke- 240. Sehingga tipe kerja fraksi etil asetat terhadap $S$. aureus bisa dikatakan adalah bakterisid (Waluyo L., 2011). Lebih tingginya kurva fraksi etil asetat daun jambu air daripada kontrol dikarenakan warna fraksi yang ikut terukur.

Tipe kerja sediaan uji terhadap $E$. coli dengan metode turbidimetri dapat dilihat pada Tabel 3 dan Gambar 2 dibawah ini : 
Tabel 3. Perkembangan Pertumbuhan E. coli Berdasar Nilai Absorbansi Setelah Pemberian Fraksi Etil Asetat

\begin{tabular}{|c|c|c|c|c|c|c|c|c|c|c|}
\hline \multirow{2}{*}{$\begin{array}{c}\text { Sistem } \\
\text { uji }\end{array}$} & \multicolumn{10}{|c|}{ Nilai absorbansi dalam interval tiap 30 menit } \\
\cline { 2 - 11 } & $\mathbf{0}$ & $\mathbf{3 0}$ & $\mathbf{6 0}$ & $\mathbf{9 0}$ & $\mathbf{1 2 0}$ & $\mathbf{1 5 0}$ & $\mathbf{1 8 0}$ & $\mathbf{2 1 0}$ & $\mathbf{2 4 0}$ & $\mathbf{2 7 0}$ \\
\hline Kontrol & 0,041 & 0,064 & 0,127 & 0,246 & 0,332 & 0,391 & 0,468 & 0,542 & 0,536 & 0,542 \\
\hline $\begin{array}{c}\text { Fraksi etil } \\
\text { asetat }\end{array}$ & 2,799 & 2,062 & 2,087 & 2,068 & 1,945 & 1,888 & 1,940 & 1,635 & 1,448 & 1,204 \\
\hline
\end{tabular}

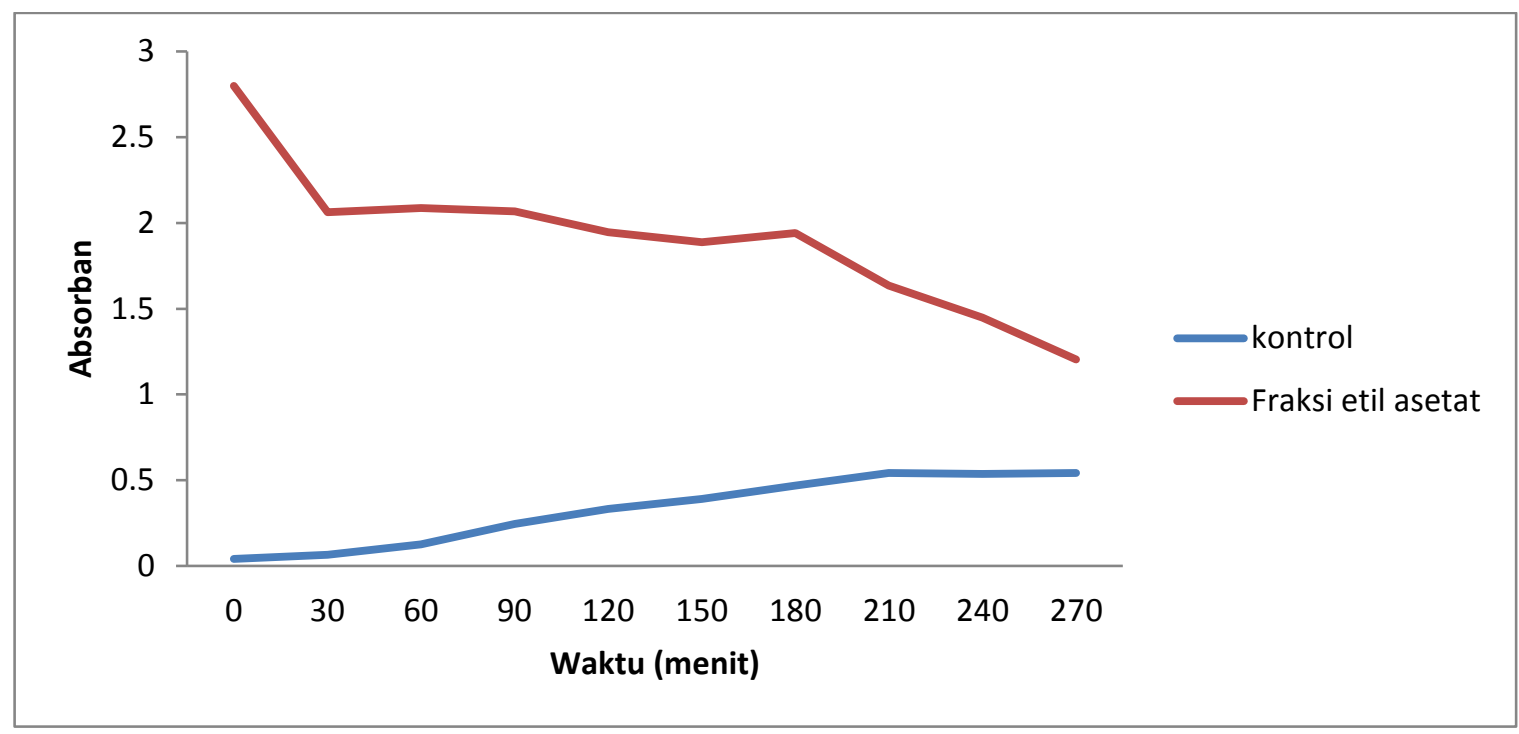

Gambar 2. Perkembangan Pertumbuhan E. coli setelah Pemberian Fraksi Etil Asetat Berdasarkan Pengamatan Nilai Absorbansi

Terlihat bahwa pada garis kurva fraksi etil asetat tidak terjadi pertumbuhan, tetapi terjadi penurunan sampai dengan menit ke270 (akhir waktu pengamatan). Sehingga tipe kerja fraksi etil asetat terhadap E. coli bisa dikatakan adalah bakterisid. Lebih tingginya kurva fraksi etil asetat daun jambu air daripada kontrol dikarenakan warna fraksi yang ikut terukur.

Aktivitas antibakteri Tetrasiklin terhadap S. Aureus dapat dilihat pada tabel 4 dibawah ini :
Tabel 4. Diameter Zona Hambat terhadap Pertumbuhan S. aureus dari Tetrasiklin pada Satu Seri Konsentrasi Uji

\begin{tabular}{|c|c|}
\hline $\begin{array}{c}\text { Konsentrasi } \\
(\boldsymbol{\mu g} / \mathbf{m L})\end{array}$ & $\begin{array}{c}\text { Diameter zona hambat } \\
(\mathbf{c m})\end{array}$ \\
\hline 8 & $3,41 \pm 0,02$ \\
\hline 16 & $3,51 \pm 0,04$ \\
\hline 32 & $3,57 \pm 0,05$ \\
\hline 64 & $3,74 \pm 0,03$ \\
\hline 128 & $3,83 \pm 0,06$ \\
\hline 256 & $4,01 \pm 0,06$ \\
\hline
\end{tabular}


Berdasarkan Tabel 4 dibuat persamaan linear dan : $y=0,0022 x+3,4918$ dengan

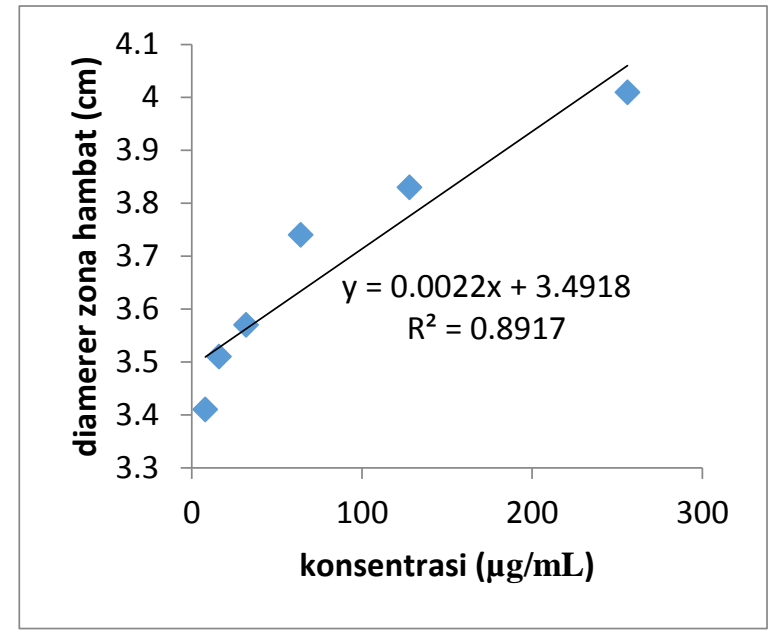

Gambar 3. Persamaan linear dari perubahan diameter zona hambat

Aktivitas antibakteri Tetrasiklin terhadap E. coli dapat dilihat pada Tabel 5 dibawah ini :

Tabel 5. Diameter Zona Hambat pada Pertumbuhan dari Tetrasiklin pada Satu Seri Konsentrasi

\begin{tabular}{|c|c|}
\hline $\begin{array}{c}\text { Konsentrasi } \\
(\mathbf{p p m})\end{array}$ & $\begin{array}{c}\text { Diameter zona hambat } \\
(\mathbf{c m})\end{array}$ \\
\hline 8 & $2,79 \pm 0,04$ \\
\hline 16 & $2,98 \pm 0,09$ \\
\hline 32 & $3,15 \pm 0,07$ \\
\hline 64 & $3,25 \pm 0,11$ \\
\hline 128 & $3,56 \pm 0,11$ \\
\hline 256 & $3,76 \pm 0,12$ \\
\hline
\end{tabular}

Berdasarkan data pada Tabel 5 diperoleh persamaan linear : $y=0,0036 x+$ 2,95 dengan nilai $\mathrm{R}^{2}=0,8725$.

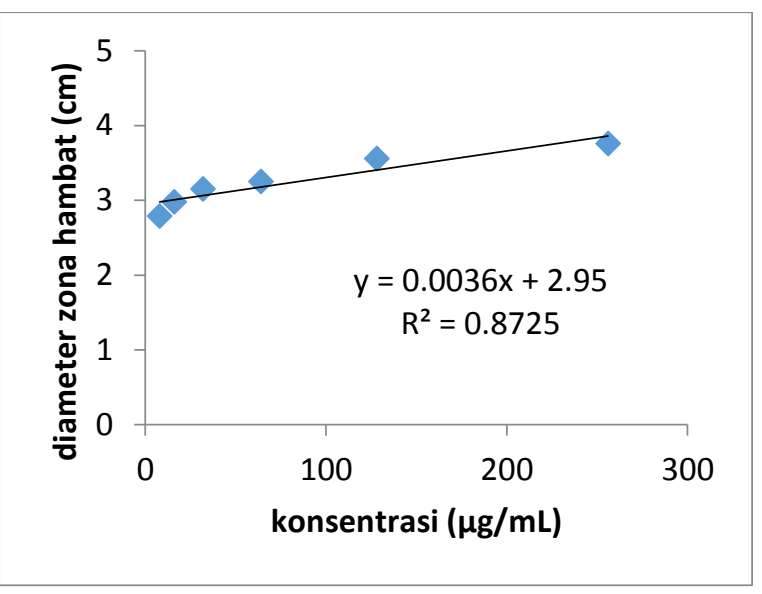

Gambar 4. Persamaan linear dari perubahan diameter zona hambat

Berdasar persamaan linear di atas, diperoleh kesetaraan aktivitas terhadap $S$. aureus, yaitu dari $1 \mathrm{~g}$ fraksi etil asetat adalah 0,0295 g tetrasiklin. Dan terhadap E. coli adalah $0,0186 \mathrm{~g}$ tetrasiklin.

\section{KESIMPULAN}

Fraksi etil asetat daun jambu air dapat dikatakan memiliki potensi sebagai antibakteri. Aktivitas sebagai anti bakteri terhadap S. aureus dan E. coli dengan nilai KHM masing-masing 12,50\%. Tipe kerja fraksi etil asetat cenderung bakterisid baik terhadap S. aureus maupun E. coli. Kesetaraan aktivitas terhadap S. aureus dari 1 $\mathrm{g}$ fraksi etil asetat terhadap tetrasiklin adalah 0,0295 g sedangkan terhadap E. coli adalah $0,0186 \mathrm{~g}$.

\section{DAFTAR PUSTAKA}

Anita A., Khotimah S., Yanti H., 2014. Aktivitas Antibakteri Ekstrak Daun Benalu Jambu Air (Dendropthoe pentandra (L.) Miq) Terhadap Pertumbuhan Salmonella typhi, Protobiont, 3(2): 268 - 272 
Aponno JV., Yamlean PVY., dan Supriati HS., 2014. Uji Efektivitas Sediaan Gel Ekstrak Etanol Daun Jambu Biji (Psidium guajava Linn) terhadap Penyembuhan Luka yang Terinfeksi Bakteri Staphylococcus aureus pada Kelinci (Orytolagus cuniculus), Pharmacon Jurnal Ilmiah Farmasi-UNSRAT, 3(3): 279-286

Cosgrove SE., Sakoulas G., Perencevich EN., Schwaber MJ., Karchmer AW., dan Carmeli Y.,2003. Comparison of Mortality Associated with Methicillin-Resistant and Methicillim-Susceptible Staphylococcus aureus Bacteremia : A Meta-Analysis, 36: 53-59

Croncuist A., 1981. an Integrated system of Classification of Flowering Plants, New York: Columbia University Press: 639643.

Departemen Kesehatan Republik Indonesia, 1985. Cara Pembuatan Simplisia, Direktorat Jenderal Pengawasan Obat dan Makanan, Jakarta: 4-15.

Hamidah S., dan Tanzerina N., 2017. Bioactive Compound of Syzygium zeylanicum Leaves As the Escherichia coli and Staphylococcus aureus Antibacterial, Biovalentia: Biological Research Journal, 3(1): 26-75

Hariyati T., Jekti DSD., dan Andayani Y., 2015. Pengaruh Ekstrak Etanol Daun Jambu Air (Syzygium aqueum) terhadap Bakteri Isolat Klinis, Journal Penelitian Pendidikan IPA. 1(1) : 31-38.

Nugraha AS., Suwendar, Hazar S., 2016. Potensi Antimikroba dari Rebusan Biji Kopi Robusta (Coffea canephora L) terhadap Bakteri Staphylococcus. aureus, Escherichia coli dan Jamur Candida albicans, Prosiding Farmasi Seminar Penelitian Sivitas Akademika Unisba, 2(2): 407-411.

Poeloengan M., dan Praptiwi., 2010. Uji Aktivitas Antibakteri Ekstrak Kulit Buah
Manggis (Garcinia mangostana Linn), Media Litbang Kesehatan, 20(2): 65-69.

Ratna RD., Ardani US., Fathiana Z., Rahmatillah A., dan Trisharyanti IDK., 2016. Daya Antibakteri Ekstrak dan Fraksi-Fraksi Daun Jambu Mete (Anacardium occidentale L.) terhadap Bakteri Staphylococcus aureus Sensitif dan Multiresisten, Jurnal Kefarmasian Indonesia, 14(1): 103-110

Rosidah dan Afizia WM., 2012. Potensi Ekstrak Daun Biji sebagai Antibakterial untuk Menanggulangi Serangan Bakteri Aeromonas hydrophila pada Ikan Gurame, Jurnal Akuatika, 3(1): 19-27

Rybak MJ., dan Aeschlimann JR., 2008. Laboratory Tests to Direct Antimicrobial Pharmacotherapy, in DiPiro, Talbert, Yee, Matzke, Wells, Posey, Pharmacotherapy a Pathophysiologic Approach, $5^{\text {th }}$ ed., McGraw Hill, New York, USA: 17151726.

Sukandar EY., Suwendar, Ekawati E., 2006. Aktivitas Ekstrak Etanol Herba Seledri (Apium graveolens) dan daun urang aring (Eclipta prostata (L.)L. terhadap Pityrosporum ovale, Majalah Farmasi Indonesia. 17(1):7-12

Suwendar dan Hazar S., 2013. Evaluasi Aktivitas Antioksidan Fraksi Non-polar ekstrak etanol daun jambu air [Eugenia aqueum (Burm. F) Alston] secara in vitro dengan Metode Carotene Bleaching, Jurnal Ilmiah Farmasi Asy-Syifa, 1(2): 1-4 Suwendar, Hazar S., dan Subarnas A., 2014. Uji Aktivitas Antioksidan Ekstrak Etanol Daun Jambu Air [Eugenia aqueum (Burm. F) Alston] secara in vitro dengan Metode Carotene Bleaching, Prosiding Seminar Nasional Penelitian dan Pengabdian pada Masyarakat : Sains, Teknologi dan Kesehatan, 4(1) : 31-36.

Waluyo L., 2011. Mikrobiologi Umum, Edisi Revisi, UMM Press, Malang: 93-109 